"Public companies non-financial reporting and audit in Ukraine: challenges and prospects"

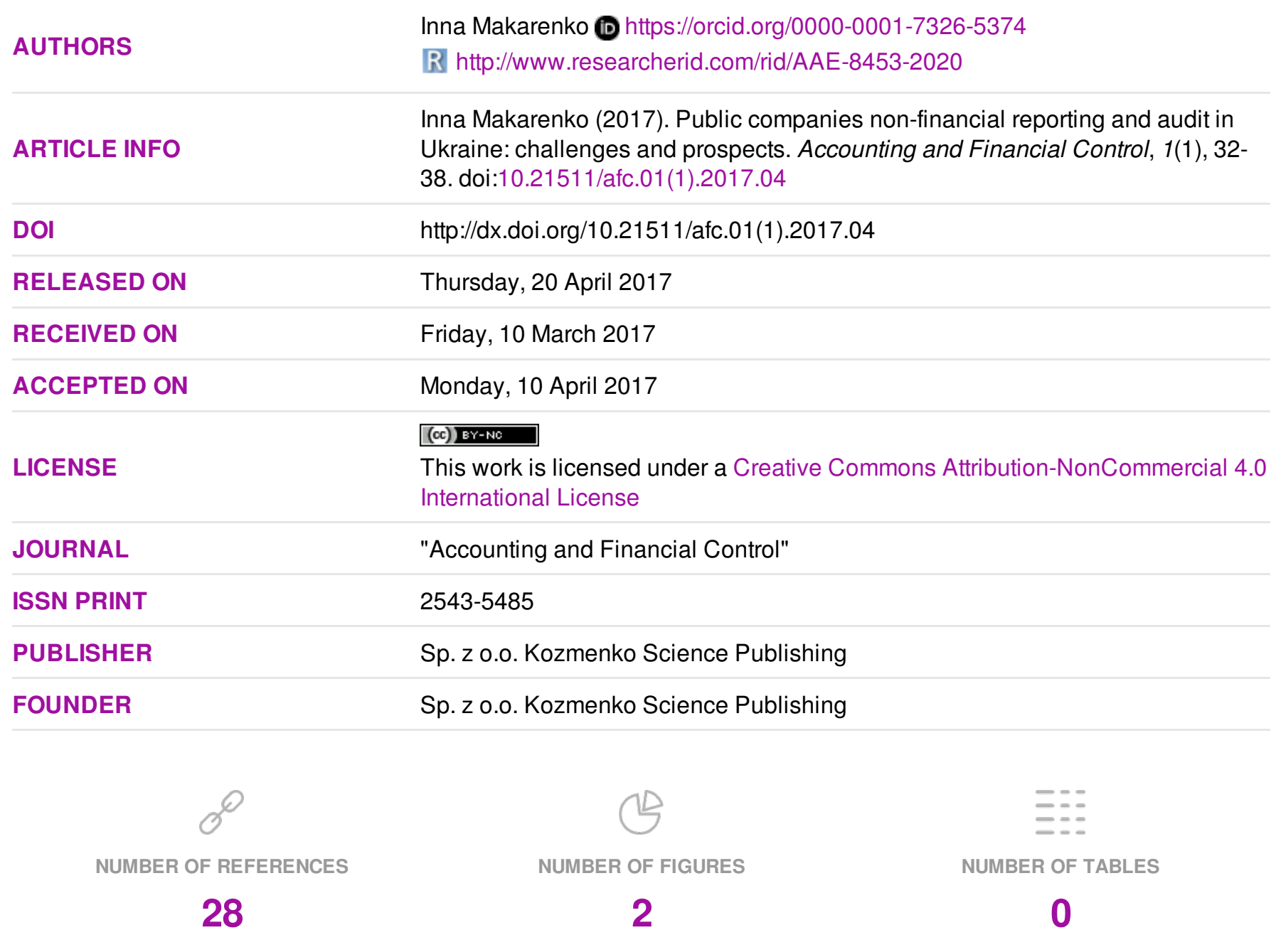

(c) The author(s) 2022. This publication is an open access article. 
Inna Makarenko (Ukraine)

\title{
Public companies non-financial reporting and audit in Ukraine: challenges and prospects
}

\begin{abstract}
Public interest entities and public companies as their representatives should be an example in implementing of sustainable development initiatives (sustainable development goals of the United Nations, development strategy "Europe-2020", "Sustainable Development Strategy" Ukraine-2020") in the light of Association agreement. Main challenges for Ukrainian public companies are non-financial information disclosure and assurance of both financial and non-financial reporting through statutory audit. Key prospects of public companies accounting system reform were outlined in this regard. This research may contribute to the existing literature in regard of identifying key areas of improving financial and non-financial information PIEs disclosure as well as its independent verification through statutory audit. This improvement should incorporate European experience and provision of Directive 2014/95 / EU, Directive 2013/34 / EU, Directive 2014/56 / EU and Regulation (EU) no. 537/2014. Among the promising areas of research, introduction of integrated reporting for Ukrainian PIEs is worth noting.
\end{abstract}

Keywords: public interest entities, public companies, non-financial information, statutory audit, verification.

JEL Classification: H82, H83, M 41, M42.

Received on: $10^{\text {th }}$ of March, 2017.

Accepted on: $10^{\text {th }}$ of April, 2017.

\section{Introduction}

In the context of sustainable development initiatives (sustainable development goals of the United Nations, development strategy "Europe-2020", "Sustainable Development Strategy" Ukraine2020"), public interest entities (PIEs) and public companies as their representatives should be an example in implementing these initiatives.

Their special economic status and strategic importance cause exceptional importance of public companies and examples of virtuous corporate conduct, implementation the policy of corporate social responsibility (CSR), forming a dialogue with the public and other stakeholders as for ensuring intergenerational equity, economic prosperity, social justice and reducing the load on the environment.

Communication basis for demonstrating progress in fulfilling the assigned to PIEs tasks is in the first the reporting of companies that in today's conditions should include non-financial information on the environmental and social dimensions of sustainable development and the auditor's report, which confirms its authenticity. Together, they provide transparency of PIEs.

The system of European legislation on the regulation of accounting and auditing of PIEs in response to post-crisis challenges of globalization in recent years has undergone significant changes. In particular, there had been adopted several key documents: Directive 2013/34/EU of the European

(C) Sp. z o.o. Kozmenko Science Publishing, 2017.

Inna Makarenko, Ph.D., Associate Professor, Accounting and Tax Department, Sumy State University, Ukraine.
Parliament and of the Council of 26 June 2013 on the annual financial statements, consolidated financial statements and related reports of certain types of undertakings, amending Directive 2006/43/EC of the European Parliament and of the Council and repealing Council Directives 78/660/EEC and 83/349/EEC, Directive 2014/56/EU of the European Parliament and of the Council of 16 April 2014 amending Directive 2006/43/EC on statutory audits of annual accounts and consolidated financial statements, Regulation (EU) no. 537/2014 of the European Parliament and of the Council of 16 April 2014 concerning specific requirements relating to statutory audits of public interest entities, Directive 2014/95/EU of the European Parliament and of the Council of 22 October 2014 amending Directive 2013/34/EU as regards disclosure of non-financial and diversity information by certain large undertakings and groups.

The need for implementing these Directives in national accounting regulation of state enterprises is due not only to the obligations taken by Ukraine within the Association Agreement (2014) in the part of the reform of accounting, auditing, management of public enterprises, but also because of inefficient operations and non-transparency of these companies. According to reports on the implementation of the Association Agenda and Association Agreement between Ukraine and the European Union for 2015 and 2016 of the Government Office for European Integration of the Secretariat of the Cabinet of Ministers of Ukraine it was made a particular progress in implementing international standards in the administration of 
unitary public companies and developed a draft law aimed at strengthening requirements for audit and disclosure of these subjects.

The purpose of the article is to analyze the reporting and auditing of Ukrainian public enterprises in the light of adaptation to the requirements of European legislation.

A key problem that characterizes reporting system of Ukrainian public companies in general (regardless of individual leaders, including Energoatom) lies in the fact that the mechanisms of disclosure of these enterprises, its confirmation by independent auditors just begin to grow and are on the initial stage of adaptation to European accounting legislation. It is proved that increasing transparency in public enterprises of Ukraine lies is in the plane of implementation of the EU requirements regarding additional disclosure of non-financial information by such companies as a part of the annual report and carrying out their statutory audit.

The author formulated the main features of the preparation, publication and audit of reports (including non-financial ones) by Ukrainian public companies, described the level of their transparency. The study proved the need for amending the law of Ukraine on the direct recognition of public companies PIEs. Basing on the analysis carried out, the ways of increasing transparency of public enterprises in the context of implementing the provisions of Directive 2014/95 / EU, Directive 2013/34 / EU, Directive 2014/56 / EU and Regulation (EU) no. 537/2014 were suggested.

\section{Literature review}

Further standard-setting initiatives to strengthen the $\mathrm{EU}$ requirements for non-financial, diversified information disclosure, enhancing transparency and statutory audit of public interest companies are accompanied by in-depth study of academic circles.

In particular, the implementation of Directive 2014/95 / EU by large companies and PIEs in the European accounting system and individual member countries are described in the works of Szabó and Sørensen (2015), Szabó and Sørensen (2016), Monciardini D. (2016), Kinderman (2015), Hąbek and Wolniak (2016).

Cross-cultural CSR reporting comparative analysis on the example of the largest corporations in the US and EU was made by Hartman, Rubin, Dhanda (2007), Tschopp (2005).

The question of implementation of Directive 2014/56 / EU and Regulation (EU) no. 537/2014 is the subject for a wider study.
While discussing the key provisions of the EU Green Paper on audit the work by Humphrey et. al (2011) is worth mentioning. The issue of post-crisis development of the audit profession in the light of updated regulatory requirements is raised by Fulop, Pintea (2014). Comparative research on new requirements for statutory audit of the most important international regulators such as the International Auditing and Assurance Standards Board (IAASB), European Union (EU), Public Company Accounting Oversight Board (US PCAOB) and the UK Financial Reporting Council was conducted by Kiss, Fulop, Cordos (2015).Cross-national comparison of audit regulation modes of socially significant companies by Kleinman, Lin, Palmon (2014) allowed identifying challenges and obstacles to national, international auditor oversight reasoned by the variety of auditing standards used.

Some practical aspects of the implementation of Directive 2014/56 / EU and Regulation (EU) no. $537 / 2014$ concerning assurance of audit reports quality of socially significant companies, the role of audit committees and the prohibitions of non-audit services on the example of the EU companies are also widely reflected.

Research of quality and structure of audit reports during the statutory audit of listed socially significant companies in the EU due to the requirements of professional standards was conducted by Botez D. (2014), Botez D. (2015).

Van der Elst (2014) draws attention to the role of audit committees of socially significant companies in the EU.

In their writings Causholli, Chambers, and Payne (2014), Causholli, Chambers, and Payne (2015) thoroughly tested the hypothesis about the impact of non-audit services on auditor independence and the works by Ratzinger-Sakel and Schoenberger (2015), Campa, Donnelly (2016) highlight the importance of separation of audit and non-audit services provided to socially significant companies in the EU.

Some aspects of the implementation of accounting directives in practice of Ukrainian PIEs according to implementation of the Association Agreement with the EU are revealed in the works of Ukrainian scientists: Golov (2014), Zubilevich (2014), Parkhomenko (2014), Petryk (2014). However, these authors' achievements are not actualized with the adoption of Directive 2014/95 / EU.

EU regulatory documents concerning statutory audit of PIEs are the subject of research in the study of Dorosh N. (2015), Red'ko O. (2015), Shalimova 
(2016) and Shulga (2015). But a new draft Law "On the audit of financial statements and audit activity" from 02.03.2017 rises a new issue to be analyzed concerning compliance of national legislation in the field of PIEs auditing with the EU practice.

It should also be noted that Ukrainian and foreign scientists had paid a few attentions not only to accounting, disclosure of information in public enterprises, but also to its audit and verification mechanism.

\section{Public companies' non-financial reporting}

The adoption on the 12th of June 2014 and publication in the Official Journal of the European Union on the 15th of December 2015 of Directive on the disclosure of non-financial and diversity information by certain large undertakings and groups (2014/95/EU) obliged member countries to join on the highest legislative level through mechanisms of sustainability development information disclosure to realization of Objectives 12.6 and the Strategy "Europe - 2020". According to Directive 2014/95 / EU large companies and PIEs from the 1 st of January 2017 , i.e. for the year of 2017-2018, have to disclose additional non-financial information in their statements.

In the framework of the Association Agreement with the EU of 27.06.2014 Ukraine during the same period (starting from 2017) undertook an obligation to implement European law norms into national practice. In particular, this is referred to changes in the accounting, reporting and auditing. Despite the fact that the Directive 2014/95 / EU was adopted after the signing of the agreement, the disclosure of non-financial information on sustainable development and promotion of CSR practices are uncontested ways to increase competitiveness and investment attractiveness of Ukrainian public companies in the European markets.

Given the construction principle of the Directive "report or explain", large undertakings which are public-interest entities exceeding on their balance sheet dates the criterion of the average number of 500 employees during the financial year shall include in the management report a non-financial statement containing information to the extent necessary for an understanding of the undertaking's development, performance, position and impact of its activity, relating to, as a minimum, environmental, social and employee matters, respect for human rights, anti-corruption and bribery matters, including

- social and employee aspects;

- respect for human rights;

- anticorruption and bribery issues;
- diversity in board of directors;

- environmental matters.

Provisions of Directive 2014/95 / EU, which has a non-regulatory nature is quite flexible in terms of the selection by companies of national or international guidelines for reporting on sustainable development or CSR policy formation. The main ones worth mentioning are:

- United Nations Global Compact;

- United Nations Guiding Principles on Business and Human Rights;

- ISO 26000 Guidance Standard on Social Responsibility;

- International Labor Organization Tripartite Declaration of Principles concerning Multinational Enterprises on Social Policy;

- OECD Guidelines for Multinational Enterprises, Guidelines of Global Reporting Initiative;

- OECD Due Diligence Guidance for Responsible Supply Chains of Minerals from ConflictAffected and High-Risk Areas;

- EMAS etc.

In the context of compliance with the rules of Directive 2014/95 / EU, according to the study of Transparency index by the Center "CSR Development" the analysis of public companies' disclosure compliance with the Directive was carried out. Thus, the state of disclosure of financial statements of public companies can be described as very low. At the time of the research of the Center in 2015 nearly half of public companies placed online financial report on the website (24 of 60). However, the auditor's report to the financial statements was released by 16 of them. According to the latest data of the Ministry of Economy and Development as of 17.08.2016, 26 of the largest public companies from 45 ones had not published financial statements with the auditor's conclusion.

Regarding CSR Strategy and non-financial reporting (Figure 1), their disclosure is critically low.

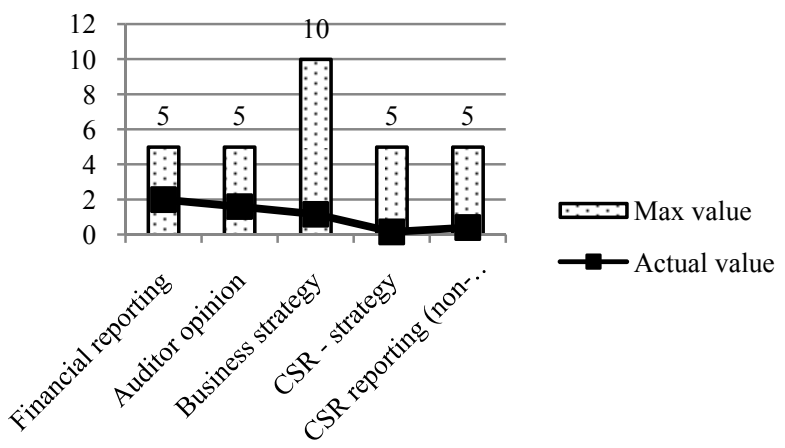

Fig. 1. The level of CSR disclosure on websites of companies on the parameter of "Strategy and Reporting" points, Center "CSR Development" (2015) 
Only 4 companies declared their CSR - strategy and priorities (State Enterprise "National Nuclear Energy Generating Company "Energoatom", State Food and Grain Corporation of Ukraine, PJSC "Ukrhidroenergo" and PJSC "Tsentroenergo"). No site contained CSR - report, but some companies have started to prepare reports on the activities of enterprises according to the Order of the Ministry of Economic Development and Trade of Ukraine of 11.02.2015 № 116 and place this information on its website (PJSC "Ukrhidroenergo", PJSC "Tsentroenergo", SE "Ukrkosmos" and the
National energy company "Ukrenergo", SE "National Nuclear Energy Generating Company "Energoatom") (Center "CSR Development" (2015).

Analyzing the level of CSR information disclosure in these reports in terms of the directions laid down in Directive 2014/95 / EU, it is worth noting that there is a very low level of disclosure regarding components of "Development and support of the community", "Human rights" and "Ecology" (Figure 2).

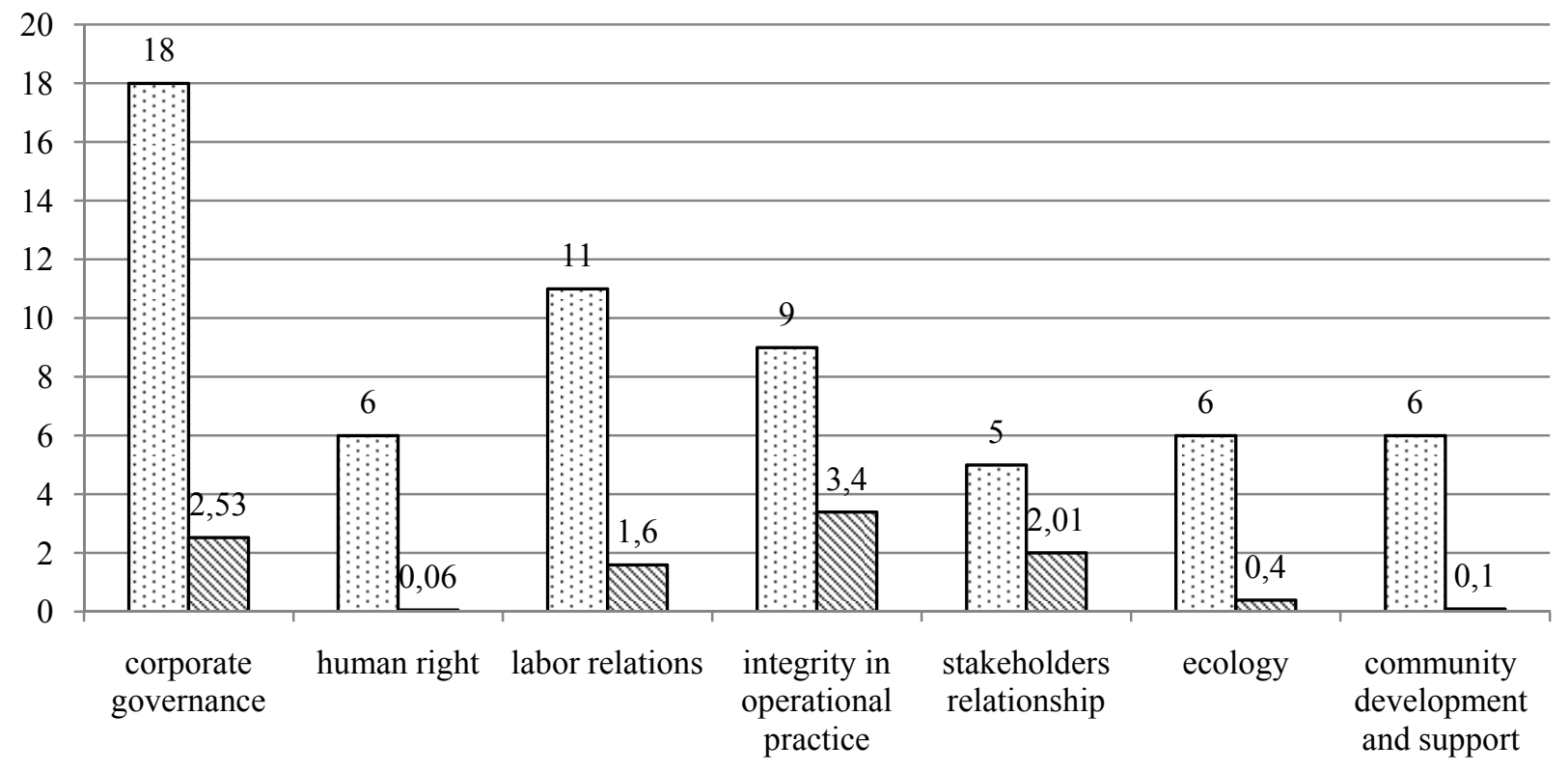

$\square$ Max value $\Delta$ Actual value

Fig. 2. The level of disclosure on the websites of companies on the parameter of "Content", points, Center "CSR Development" (2015)

No company sites which were evaluated had provided information on:

- policy on wages, bonuses, awards for management (issue of the component of "corporate governance");

- policy on employment of people with disabilities, human rights (issue of the component of "corporate governance");

- results of environmental audits and penalties (issue of the component of "ecology").

Other CSR issues are revealed on the sites of only few companies.

At the same time Directive 2014/95 / EU requires companies to publish not only defined categories of non-financial information but formalize it in managers' reports. Along with this, the companies must submit a report on corporate governance and a report on payments to government.
Management report provides a reliable overview of the development, operation and condition of the company and a description of the main risks and uncertainties it faces. It includes both financial and, where appropriate, non-financial key performance indicators concerning environmental and social issues. Report should describe the prospects for further development of the company; activities in the field of research and development; information on the acquisition of own shares according to the article; presence of branches of the company; data on the use of financial instruments and the aim and policy of the company to manage its financial risks.

Corporate governance statement should be included in the management report to disclose the following areas: reference to the Corporate Governance Code, which is guided by the company, deviation from its requirements and their explanations; description of the main characteristics of the control and risk management in connection with the process of 
preparation of the financial statements; description of the operation of shareholders 'meetings and their main powers; the composition and operation of the administrative, management and supervisory bodies and their committees.

The report on payments to government should include information on the types of payments disclosed by enterprises participating in the Extractive Industries Transparency Initiative (EITI), the Action Plan of the European Union «enforcement, governance and trade in forest sector» (EU FLEGT) and the provisions of Regulation (EC) № 995/2010 of the European Parliament and of the Council of 20 October 2010, which set out the mandatory requirements for operators on timber and wood products market. Among the Ukrainian public companies "Naftogaz Ukraine", "Coal of Ukraine", "Coal" Krasnolymanska", "Lisichanskugol" and other similar companies have to draw up this report.

Public companies as RIEs should disclose the amount of payment in case of exceeding them EUR 100000 in terms of categories such as income from production; income tax, tax on production or earnings, other than consumption taxes such as value added tax, income tax on individuals or sales tax; royalties; dividends; discount on signing the contract, bonus for the discovery of mineral resources and production bonuses; license fees, rental fees, entry fees and other charges for licenses and / or receiving concessions; and payments to improve infrastructure.

At the time of the survey reports on payment to government were not published by no one Ukrainian public companies.

Thus, the question of public companies nonfinancial reporting and its role in increasing transparency of their activities remains open and requires the development of methodology for disclosure on environmental, economic and social dimensions of sustainable development. Issues on assurance of public companies non-financial reporting have been also urgent.

\section{Public companies audit}

Audit as a tool to verify the accuracy of reporting (both financial and non-financial) for public companies as the PIEs plays a very important role to improve their transparency. However, the public companies audit, as well as their transparency and disclosure of financial and non-financial information requires a significant regulatory intervention. Among the 45 particularly important public companies, despite the legal requirement to publish annual audited financial statements 11 companies $(24 \%)$ of the surveyed did not conduct such audits as of 17.08.2016 p.

Moreover, national systems of audit regulation compliance with European Directives in view of the conditions of the Association Agreement and the Strategy for Sustainable Development "Ukraine 2020" requires detailed analysis.

Late and incomplete implementation of the Directive 2006/43 / EC in Ukrainian auditing community has meant that under European Commission Decision of 19.01.2011 was established the fact of failure of Ukraine to the EU audit requirements for "third countries". As a result, Ukrainian auditors have lost a unique opportunity to use the simplified procedure of registration and the proceedings on the European audit services markets. Later, with the adoption of the 56th Directive and Regulation EU No. 537/2014 differences between national and European audit system, including PIEs statutory audit, were only deepened.

The key challenges should be presented as follow:

- Creation a system of public oversight on the audit profession and delineation professional self-regulation functions.

- Create two-tier system of audit quality control, including strengthening the requirements for a PIEs statutory audit.

- Increasing the qualification and attestation requirements for auditors, whose clients are PIEs, tightening the requirements for their independence, rotation and limiting joint provision of audit and non-audit services.

- Create audit committee in PIEs.

Draft Law "On auditing the financial statements and audit activities", which is designed according to the requirements of 56th Directive was called to neutralize these challenges.

However, specific regulation that bypass basic law on auditing in Ukraine in regulating of public companies audit was adopted by the Cabinet of Ministers of Ukraine.

Cabinet of Ministers Regulation №390 of 4.06. 2015 "Some questions for audit entities in the public sector" sets up stringent criteria for the selection of independent audit firms for particularly important for the economy of public enterprises (assets exceeding 2 billion UAH or the amount of net income exceeding 1.5 billion UAH per year). Similar, but less stringent criteria were set up for the independent audit companies that conduct audits for PIEs, whose assets exceed more than $250 \mathrm{mln}$. UAH. 
Reaction of the professional audit community on the adoption of this document is ambiguous because it can create preferences for certain audit companies large audit networks. Hard and sometimes unmotivated requirements for qualification and number of auditors create obstacles for local audit firms to enter the market of public companies' audit.

Analysis of particularly important public companies' auditor opinion showed that of the 45 companies only PJSC "Sumykhimprom" was audited by LLC "Audit Firm" ARCA" and SE "Ukrspetsexport" was audited by LLC "Audit Firm "BInA" that is the Ukrainian auditing companies. Among particularly important public companies share of the Big 4 account for $22 \%$ of clients, the company's middle-tier (BDO and Backer Tilly) $-47 \%$.

This market situation directly contradicts the aim of 56th Directive and Regulation EU number 537/2014 on increasing competition on the audit services market and its quality.

Separate issue rises concerning verification public companies non-financial reporting as part of the annual report. Lack of methodologies for such services in Ukraine may have an adverse effect on increasing public companies reporting transparency.

\section{Conclusion and remarks}

To sum up, it is worth noting that public companies as strategically important and economically powerful Ukrainian companies in the context of European integration should implement the EU Directives (34th, 56th and 95th, the Regulation EU No. 537/2014), Association Agreement with the EU and sustainable development initiatives. 95th Directive sets up the principle "report or explain" in non-financial reporting for large undertakings which are PIEs exceeding on their balance sheet dates the criterion of the average number of 500 employees during the financial year. These PIEs in Ukraine were mainly represented by public companies. They should include in the management report a non-financial statement containing information to the extent necessary for an understanding of the undertaking's development, performance, position and impact of its activity, relating to, as a minimum, environmental, social and employee matters, respect for human rights, anticorruption and bribery matters

At the same time this Directive requires companies to publish not only defined categories of nonfinancial information in managers' reports but also submit a report on corporate governance and a report on payments to government. Management report, report on corporate governance and a report on payments to government is not widely recognized by Ukrainian accounting regulators and need to be formalized.

As for the public companies audit the main challenges are concerned creation a system of public oversight on the audit profession, two-tier system of audit quality control, including strengthening the requirements for Ukrainian PIEs statutory audit, increasing the qualification and attestation requirements for auditors, whose clients are PIEs, rotation and limiting joint provision of audit and nonaudit services in the light of 56th Directive and Regulation (EU) no. 537/2014. Among the promising areas of research, introduction of integrated reporting for Ukrainian PIEs is worth noting.

\section{References}

1. Botez, D. (2014). New requirements for statutory auditors in European Union. New Studies and Scientific Researches. Economics Edition, 20, 37-43.

2. Botez, D. (2015). Aspects Regarding the Quality of Statutory Audit Reports. Audit Financier, 13(123), 82-89.

3. Directive 2013/34/EU of the European Parliament and of the Council of 26 June 2013 on the annual financial statements, consolidated financial statements and related reports of certain types of undertakings, amending Directive 2006/43/EC of the European Parliament and of the Council and repealing Council Directives 78/660/EEC and 83/349/EEC, Available at: http://eur-lex.europa.eu/legal-content/EN/ALL/?uri=CELEX:32013L0034

4. Directive 2014/56/EU “On statutory audits of annual accounts and consolidated accounts", Retrieved from: http://eur-lex.europa.eu/legal-content/EN/TXT/?uri=celex\%3A32014L0056.

5. Directive 2014/95/EU of the European Parliament and of the Council of 22 October 2014 amending Directive 2013/34/EU as regards disclosure of non financial and diversity information by certain large undertakings and groups, Official Journal of the European Union L 330/1, Retrieved from: http://eur-lex.europa.eu/legalcontent/EN/TXT/?uri=CELEX:32014L0095

6. Dorosh, N. (2015). Rozvytok audytors'koyi diyal'nosti v Ukrayini v umovakh yevrointehratsiynykh protsesiv, Visnyk Kyyivs'koho natsional'noho universytetu imeni Tarasa Shevchenka, 10, 17-23.

7. EU-Ukraine Association Agreement 27.06.2014, Retrieved from: http://eeas.europa.eu/archives/ delegations/ukraine/eu_ukraine/association_agreement/index_en.htm

8. Fulop, M., and Pintea M. (2014). Effects Of The New Regulation And Corporate Governance Of The Audit Profession SEA - Practical Application of Science. Fundația Românăpentru Inteligența Afacerii, Editorial Department, 4, 545-554. 
9. Healy, P., Hutton, A., Palepu, K. (1999). Stock performance and intermediation changes surrounding sustained increase in disclosure. Contemporary Accounting Research, 3(16), 485-520.

10. Holov, S. (2014). Rehulyuvannya bukhhalters'koho obliku I audytu v YeS ta vyklyky dlya Ukrayiny. Bukhhalters'kyy oblik i audyt, 10, pp. 3-13.

11. Humphrey, C. et al. (2011). Regulating Audit beyond the Crisis: A Critical Discussion of the EU Green Paper. European Accounting Review, 20(3), 431-457.

12. Hura, N. (2015). Implementatsiya dyrektyvy 2013/34/EU v Ukrayini z urakhuvannyam mizhnarodnoho dosvidu. Visnyk Kyyivs 'koho natsional'noho universytetu imeni TarasaShevchenka, 10, 6-10.

13. Center "CSR Development" (2015). Indeks prozorosti derzhavnykh komaniy Ukrayiny - 2015. Retrieved from: http://csr-ukraine.org/article-2

14. Kiss, C. et al. (2015). Relevant Aspects Regarding the Changes of the Statutory Audit Report in the Light of International Regulations, Audit Financiar, 13(126), pp. 63-73.

15. Parkhomenko, V. (2014). Yevrokonverhentsiya bukhhalters'koho obliku, Bukhhalters 'kyy oblik $i$ audyt, 8, 3-4.

16. Petryk, O. A. (2011). Problemy adaptatsii zakonodavstva u sferi audyta do polozhen 43 Dyrektyvy EU ta Zelenoi knyhy "Polityka audytu: uroky kryzy". Visnyk Lvivskoi komertsiinoi akademii, 265-268.

17. Pro audit finansovoyi zvitnosti ta audytors'ku diyal'nist': proektZakonu vid 17.08.2015. Retrieved from: www.minfin.gov.ua/.../files/55d721ef438fe.doc

18. Pro audytors'ku diyal'nist': proekt Zakonu vid 06.10.2015. Retrieved from: http://instituteaudit.com.ua/news/24-shanovni-kolegi.html

19. Pro deyaki pytannya provedennya audytu finansovoyi zvitnosti subyektiv hospodaryuvannya derzhavnoho sektoru ekonomiky: Postanova Kabinetu Ministriv Ukrayiny № 390 vid 04.06.2015. Retrieved from: http://www.kmu.gov.ua/control/uk/cardnpd?docid=248248066

20. Proekt Zakonu pro audit finansovoyi zvitnosti ta audytors'ku diyal'nist' № 6016 vid 03.02.2017. Retrieved from: http://w1.c1.rada.gov.ua/pls/zweb2/webproc4_1?pf3511=61045

21. Ratzinger-Sakel, Nicole V. S., and Schoenberger, Martin W. (2015). Restricting Non-Audit Services in Europe -The Potential (Lack of) Impact of a Blacklist and a Fee Cap On Auditor Independence and Audit Quality (March 25). Accounting in Europe, Journal of the European Accounting Association, 21, 61-86.

22. Red'ko O. Yu. (2015). Pytannya akomodatsiy iukrayins'koho audytu do vymoh EU. Statystyka Ukrayiny, 1, 28-30.

23. Regulation (EU) № 995/2010 of 20 October 2010 laying down the obligations of operators who place timber and timber products on the market. Retrieved from: http://eur-lex.europa.eu/LexUriServ/LexUriServ.do? uri=OJ:L:2010:295:0023:0034:EN:PDF

24. Shalimova N. S. (2016). Rehulyuvannya obov'yazkovoho audytu v krayinakh EU ta Ukrayini. Stratehiya rozvytku Ukrayiny, 1, 51-56.

25. Shul'ha, S. (2015). Zminyuyuchy pravyla hry - pershi otsinky vplyvu dyrektyvy EU z audytu na yevropeys'ki ta svitovi rynky. Bukhhalters'kyy oblik i audyt, 10, 30-34.

26. Szabó, D. G., and Sørensen, K. E. (2015). New EU Directive on the Disclosure of Non-Financial Information (CSR). European Company and Financial Law Review, 12(3), 307-340.

27. Van der Elst, Christoph, Audit Committees of Public Interest Entities in Europe (December 2, 2014). European Corporate Governance Institute (ECGI) - Law Working Paper № 276/2014. Retrieved from: https://ssrn.com/abstract $=2533341$

28. Zubilevych S. (2014). Oblikova Dyrektyva EU, yiyi vplyv na sklad i zmist zvitiv y evropeys'kykh kompaniy ta perspektyvy dlya Ukrayiny. Bukhhalters 'kyy oblik i audyt, 7, 3-15. 